\title{
Blended-flipped classroom learning for physics students with the topic of the photoelectric effect
}

\author{
Alvama Pattiserlihun *, Stephanie Jessy James Setiadi \\ Department of Physics Education, Universitas Kristen Satya Wacana. \\ Jalan Diponegoro No. 52-60, Salatiga, Central Java 50711, Indonesia. \\ * Corresponding Author. Email: alvama.pattiserlihun@uksw.edu
}

Received: 11 November 2019; Revised: 23 June 2020; Accepted: 25 June 2020

\begin{abstract}
Blended-Flipped Classroom Learning is a learning method that combines blended learning with flipped classroom learning. This study aims to: (1). Design and implement Blended-Flipped Classroom Learning with the topic of Photoelectric Effect for Physics and Physics Education students in Modern Physics course; (2). Determine how the effect of Blended-Flipped Classroom Learning on student learning outcomes for the topic of Photoelectric Effect; (3). Determine students' responses toward Blended-Flipped Classroom Learning for the topic of Photoelectric Effect. This research was descriptive and conducted at the Physics and Physics Education Department, Universitas Kristen Satya Wacana in the Modern Physics course. From the results of the research conducted it can be concluded that student learning outcomes after Blended-Flipped Classroom Learning were in the "high" and "very high" category, where most students (85.7\%) were in the very high category. This result indicates that learning using Blended-Flipped Classroom Learning helps students to achieve optimal learning outcomes. Student responses to Blended-Flipped Classroom Learning were in the "good" category. It also shows that students' positive responses to the learning process can influence the optimization of their learning outcomes. This kind of learning model requires the teacher who acts as a facilitator, dynamist, evaluator and also justifier.
\end{abstract}

Keywords: blended learning, flipped classroom, physics

How to Cite: Pattiserlihun, A., \& Setiadi, S. (2020). Blended-flipped classroom learning for physics students with the topic of the photoelectric effect. Jurnal Inovasi Pendidikan IPA, 6(1), 71-78. doi:https://doi.org/10.21831/jipi.v6i1.28109

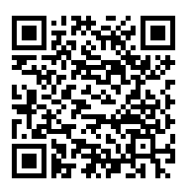

\section{INTRODUCTION}

Physics learning in Indonesia, especially in the scope of Modern Physics, both in high schools and at the university level, is still considered to be less attractive and monotonous and compounded by lack of experiments due to limited laboratory equipment related to Modern Physics subject. For this reason, we need a learning method that can utilize and combine several media and approaches for students. Learning method like this is also expected to remain oriented on Student-Centered Learning (SCL) where students are the main stars while the teacher acts as a facilitator to keep the course of learning to remain interesting, conducive, engaging and stay on track. Related to learning where students are the centre, Rukmini et al. (2018) found that SCL can improve classroom performance by as much as $46 \%$. The literature has shown that SCL increases mastery of soft skills including communication skills, teamwork, and learning motivation. This shows that SCL not only increases the hard-skills of students but also their soft-skills.

Laboratory equipment within the scope of modern Physics is also not sufficient both at secondary school level and in higher education. This is quite unfortunate because laboratory activities can facilitate the development of student skill aspects which emphasizes the ability to overcome problems through the application of scientific work, and is also related to the development of careful, disciplined and responsible character (Peniati et al., 2013). One approach to overcome this matter is to utilize virtual laboratories that are easily available online, free and have a virtually attractive appearance. One of the virtual laboratories that can be used is PhET (Physics Education Technology) media, a free online application developed by the University of Colorado. Learning with using PhET as a virtual laboratory has begun to be used in Indonesia. A study by Prihatiningtyas et al. (2006) showed that the application of simple PhET simulation and KIT were able to complete student learning outcomes and the learning 
also had positive responses from students. The positive attitudes of the students gave a positive effect on their learning outcomes. Azis (2016) found that there was a significant relationship between attitude and student learning outcomes in Biology subject, which if students liked the subject then students would approach and influence positive things in themselves so that the learning outcomes obtained would be increased.

Conventional learning can be done in reverse to make the atmosphere of learning in the classroom and independent learning outside the classroom can be more interesting so that students will feel more challenged and interested in learning. One method that can be used is the Flipped Classroom method. The flipped classroom is a method that educators can provide by minimizing the amount of direct instruction in teaching practice while maximizing interaction with one another (Johnson, 2013). The flipped classroom learning model is a model when in the learning process, students learn subject matter from the learning video at home before class begins and teaching and learning activities in class in the form of assignment and discussion of materials or problems that not understood by students. By doing assignments at school it is expected that when students experience difficulties, it can be directed consulted with friends or with the teacher so that the problem can be solved immediately (Pratiwi et al., 2017). A study related to the flipped classroom showed that the flipped classroom was able to improve learning outcomes and the ability to learn independently from students (Enfield, 2013). A research conducted by Schultz et al. (2014) showed that the flipped classroom learning model was able to increase student activity and interaction between students and teachers, especially in Chemistry subject. ArnoldGarza (2014) found that the features of the flipped classroom include a focus on class time efficiency which takes in different learners, engages with PBL, enhances student-teacher interaction, and lets students take responsibility for learning so that these skills can be transferred to other situation.

Also, it needs the right way to keep the learning and discussion process on track. One method that can be applied is to use stimulant questions, both when giving the assignment and learning in the classroom. Some studies examine stimulant questions whether they can help students in several stages of the learning process based on the scientific approach which is observing, questioning, experimenting, associating, and communicating. A study conducted by Andresta et al. (2018) found that through stimulant questions students were able to improve their communication skills in the learning process.

All the ingredients with the virtues above can be mixed through blended learning. Kim et al. (2008) stated that blended learning or hybrid learning is a learning program that blends traditional inclass learning components and e-learning components. Students can be given various e-learning materials such as e-books, videos related to the topic, and also a virtual laboratory that they can find it online. This virtual laboratory can be used in the process of learning and discussion to strengthen the concepts and knowledge related to modern physics which are generally invisibly microscopic. Oktavianti et al. (2018) also found that blended physics learning with e-scaffolding enhanced the students' scientific explanation such as claim, evidence, and reasoning. Blended learning is relevant to be implemented in Indonesian higher education to reinforce students to learn self-reliantly beyond the classroom, build the competence to collaborate and discuss with their peers in order to solve problems (Zainuddin \& Keumala, 2018). The benefits of blended learning can be utilized so that student's skills can be more developed, not only in terms of hard-skills but also in their soft-skills.

Based on the background above, this study aims to: (1). Design and implement Blended-Flipped Classroom Learning with the topic of Photoelectric Effect for Physics and Physics Education students in Modern Physics course; (2). Determine how the effect of Blended-Flipped Classroom Learning on student learning outcomes for the topic of Photoelectric Effect; (3). Determine students' responses toward Blended-Flipped Classroom Learning for the topic of Photoelectric Effect. This research is expected to give a new color for Physics learning, especially in the field of Modern Physics, so that learning can be more interesting, not monotonous, and keep the learning process as student-centered learning. This model can also be used by Physics teachers as a reference when they want to teach other concepts of Modern Physics.

\section{METHODS}

This research was descriptive and conducted at the Physics and Physics Education Department, Universitas Kristen Satya Wacana. The Modern Physics topic that being selected as the Photoelectric Effect. One of the reasons why the topic of Photoelectric was used is because the PhET program has a 
set of animation about the Photoelectric effect. This animation was used to strengthen the concept of the Photoelectric Effect at the end of the class.

The sample used was 35 students of Modern Physics class in the short semester of the academic year 2016/2017. The instruments used in this study are as follows: (1) Student questionnaire sheet; this instrument was used to determine students' attitudes toward Blended-Flipped Classroom Learning for the topic of Photoelectric Effect. This questionnaire contains 12 questions/statements with four (4) answer choices: Strongly Agree (SA), Agree (A), Disagree (D), Strongly Disagree (SD); (2) Observation sheet for student learning activity (discussion); this instrument was used to monitor students' activities in group discussions. This observation sheet consists of 5 statements and a student was appointed in each group as an observer (peer-observation); (3) Group Presentation Assessment sheet; this instrument was used to assess the performance of each group when they present their task. The assessment was divided into 5 categories, such as (1). Media used in the presentation (whiteboard/ PPT/animation/video); (2). Clarity and readiness in conveying information; (3). Completeness of the materials assigned; (4). The accuracy and mastery of the concepts; (5). Performance in front of the class (is it interactive?/interesting?/easy to understand? ). Each component was given a maximum of 20 points, so the total point is 100; (4) Evaluation sheet; this instrument was used to determine the learning outcomes of students after the learning process using the Blended-Flipped Classroom Learning method.

The data obtained were analyzed with qualitative descriptive approach. The questionnaire was given four (4) answer choices according to the context of the question or statement with their respective weights. For example "highly favorable/suitable" (4 points); "favorable/suitable" (3 points); "unfavorable/unsuitable" (2); "highly unfavorable/suitable" (1).

Assessment score can be calculated using the formula below:

Assessment score $=\frac{\text { total score of the instrument }}{\text { total of the highest score }} \times 4$

After that, the average score of the assessment score will be calculated and classified as shown in the Table 1:

Table 1. The Conversion of the Assessment Score into the Statement of Quality Value

\begin{tabular}{ccc}
\hline Assessment Score & Average Score & Classification \\
\hline 4 & $3.26-4.00$ & Very good \\
3 & $2.51-3.25$ & Good \\
2 & $1.76-2.50$ & Fair \\
1 & $1.01-1.75$ & Poor \\
\hline
\end{tabular}

(Suyanto, 2009)

Levels related to student learning activity during group discussion, group presentation, and student learning outcomes are classified according to the Table 2 .

Table 2. Assessment Classification

\begin{tabular}{ccc}
\hline Test Score & Percentage $(\%)$ & Classification \\
\hline $81-100$ & $81-100$ & Very High \\
$61-80$ & $61-80$ & High \\
$41-60$ & $41-60$ & Medium \\
$21-40$ & $21-40$ & Low \\
$0-20$ & $0-20$ & Very Low \\
\hline
\end{tabular}

(Arikunto, 2016)

The success criteria for this research were: (1) At least $80 \%$ of students get a minimum of 75 test evaluation scores; (2) At least $80 \%$ of students respond positively to Blended Learning: "Flipped Classroom".

\section{RESULTS AND DISCUSSION}

The learning process began with the division of students into groups ( 8 groups), giving the stimulant questions as the basis to do the assignment and Whatsapp (WA) group establishment. After that, students were given several learning resources such as video (related to Photoelectric Effect), ebook, and other online materials. Students were also freed to find other supporting resources online. 
Students were told that they will present their work in front of the class and the materials they bring are the subjects of joint discussion. Each group was assessed when they present the materials.

On D-day, students presented their materials based on the predetermined sequence. Discussions were held at the end of each group's presentation. During the discussion, there was a "peer-observation", wherein each group, one (1) student was appointed as the observer for his/her friends and also for him/ herself. After all presentations and discussions, the topic materials were strengthened by demonstrating the PhET Virtual Laboratory for the topic of Photoelectric Effect and the things learned on that day were also concluded.

After that, to find out the student learning outcomes related to the topic of the Photoelectric Effect, students were given an analyzing-and-problem-solving type of quiz. After the quiz, students were asked to fill the questionnaire to know their responses/attitudes towards the learning process.

The student learning outcomes and their categories can be seen in Table 3 .

Table 3. The Recapitulation of Student Learning Outcomes

\begin{tabular}{ccc}
\hline Test Score & Category & Number of Students \\
\hline $81-100$ & Very High & 30 \\
$61-80$ & High & 5 \\
$41-60$ & Medium & 0 \\
$21-40$ & Low & 0 \\
$0-20$ & Very Low & 0 \\
\hline
\end{tabular}

The Table 3 shows that student learning outcomes are in the "high" and "very high" category, where most students $(85,7 \%)$ are in the "very high" category. The result indicates that the learning process using Blended-Flipped Classroom Learning helps students to achieve optimal learning outcomes. The highest score achieved was 100 and the lowest score was 75 with an average score of 94,4. This result is linear with a study related to blended learning that produced good student learning outcomes. Husamah (2015) found that blended project-based learning is effective to develop new students' thinking skills. One indicator that shows the cognitive abilities of students' thinking can be determined from their learning outcomes. This shows that blended learning even with different approaches/variants can still produce very satisfying student learning outcomes. Students were also assigned to present their assignments in front of the classroom. Their performance was assessed based on several criteria as mentioned in the methods. The results of the group presentation assessment are shown in Table 4.

Table 4. Presentation Score

\begin{tabular}{ccc}
\hline Group & Score & Category \\
\hline 1 & 79 & High \\
2 & 88 & Very High \\
3 & 85 & Very High \\
4 & 78 & High \\
5 & 91 & Very High \\
6 & 80 & High \\
7 & 78 & High \\
8 & 80 & High \\
Average & 82.375 & Very High \\
\hline
\end{tabular}

The presentation score Table 4 shows that all groups had good grades regarding their performance in carrying out their assignments in the form of a presentation. The average score for their performance was 82,375 , which in the "Very High" category. All groups used Power Point as media to present their assignment, added with video and they also wrote some of their explanations on the whiteboard. A research conducted by Soimah (2018) shows that the learning process using computer-based media (PowerPoint) produced higher learning outcomes compared to the learning outcomes from the direct (conventional) learning method. This can be connected with the result of this study which if the students do their PowerPoint presentation well so that it can be reflected in their good learning outcomes too. In this study, $85,7 \%$ of student learning outcomes are in the "Very high" category and the student presentation scores indicate that the average of group presentation was in the "Very high" category too.

During the discussions in the classroom, student learning activities were observed too. This observation activity was carried out by one of the students in each group. The result of the observation of student learning activity can be seen in Table 5 . 
Jurnal Inovasi Pendidikan IPA, 6 (1), 2020 - 75

Alvama Pattiserlihun, Stephanie Jessy James Setiadi

Table 5. The Result of the Group Learning Activity

\begin{tabular}{ccc}
\hline Group & Percentage $(\%)$ & Category \\
\hline 1 & 92 & Very High \\
2 & 90 & Very High \\
3 & 100 & Very High \\
4 & 100 & Very High \\
5 & 100 & Very High \\
6 & 100 & Very High \\
7 & 100 & Very High \\
8 & 100 & Very High \\
Average & 97,75 & Very High \\
\hline
\end{tabular}

The Table 5 shows that student learning activities in all groups are in the "Very high" category. That particular result shows that most students $(97,74 \%)$ were active in discussion activities. BlendedFlipped Classroom Learning helps students to build their competence to collaborate and discuss with their peers to solve problems which is linear with the study of Zainuddin and Keumala (2018). The activeness of students in the discussion was stimulated by stimulant questions that had been given to them before so that students had enough preparation before they joined the class. This method is quite effective because students' initial knowledge can be developed in the discussion process so that the discussion itself can be more useful, hands-on and richer. Peer observation was beneficial because the observers were their friends so that the discussion activity was more relaxed and there was no pressure of being observed by "the outsiders". The students also remained "being themselves" when the class/discussion activity was being carried out. A relaxed-but-efficient classroom is a great environment for students to not only enjoy the learning process but also be able to express their thoughts and become more confident. Machin (2012) also found that a good way of learning is an environment without pressure and coercion. This further shows us that the learning environment can greatly influence students' moods and learning outcomes. Where if the learning environment is conducive, relaxed and constructive it will be reflected in good learning outcomes as well. The teacher or instructor needs to pay further attention to these "learning environment issues" so that students not only get good grades but also enjoy the class they attend.

After the learning process, students were given a questionnaire to know their responses and attitudes toward the learning process by using the Blended-Flipped Classroom Learning method. The result can be seen in Table 6 .

Table 6. Students' Responses Toward the Learning Process

\begin{tabular}{ccc}
\hline Item & Average Score & Category \\
\hline 1 & 3.23 & Good \\
2 & 3.17 & Good \\
3 & 3.23 & Good \\
4 & 3.13 & Good \\
5 & 3.23 & Good \\
6 & 3.07 & Good \\
7 & 3.13 & Good \\
8 & 3.10 & Good \\
9 & 3.10 & Good \\
10 & 3.23 & Good \\
11 & 3.13 & Good \\
\hline
\end{tabular}

From the Table 6, it can be seen that students' responses toward the Blended-Flipped Classroom Learning method were in the "Good" category. The lowest average score was on item 6 ("Giving "homework/assignments "before teaching and learning activities help me to follow the course of lectures (discussions and presentations) better"). The highest points were on item 1 ("I feel that Whatsapp helps me to express questions, statements or things that I cannot ask in class."), item $\mathbf{3}$ ( "Giving "homework /assignment" a week before teaching and learning activity takes place helps me to prepare the materials better.), item 5 ("Materials provided such as videos, e-books, hard-books, and other online materials help me to do the assignments well") and item 10 ("Blended-Flipped Classroom 
Learning (A COMBINATION of giving "homework/assignments" beforehand (with stimulant questions, videos, e-books and other online materials), pre-discussion via WA, then discussion and presentation under the guidance of a lecturer in the classroom, and strengthening the concepts by using PhET media) makes me understand the concepts/materials provided better").

It can be seen that although students consider that "giving assignments/homework a week before the teaching and learning activities take place" helps them to prepare the material provided better (item 3 ), but the lowest point (even though still in the good category) was on item 6 shows that the homework/assignment does not necessarily help them to follow the course well. This indicates that students still need teachers as the manager, facilitator, mediator, source of information and confirmer in the presentation and discussion process. Sanjaya (2016) found that the role of the teacher in the learning process is the teacher as a learning resource, facilitator, manager, demonstrator, guide, motivator, and evaluator. As a facilitator, a teacher has roles to provide services to facilitate students in the learning process. In implementing a learning method based on the student activity, the teacher no longer serves as the only source of learning but more importantly is how to facilitate student learning. The facilitator is more focused on facilitating and as a person who offers or provides learning opportunities (Rogers, 1983: Kadir, 2006). Ilahi and Imaniyati (2016) in his research found that the teacher's role as a manager influences the effectiveness of the teaching and learning process, which is seen in terms of the management of learning resources, time and class organization.

The information presented in Table 3, about student learning outcomes and Table 6 about students' responses can provide more information in this study. We can see that students' responses to the learning process are leaning to the positive side. Positive responses or attitudes towards learning can increase student motivation to learn so that it is reflected in the learning outcomes, which most students $(85.7 \%)$ in this study were in the "Very high" category. Research conducted by Agustya and Soejoto (2017) and Mulyana et al. (2013) also shows that there is a very strong positive relationship between students 'responses and student learning outcomes, where if students have a positive attitude towards the learning process, then student learning outcomes will be good. This implies that the selection of learning strategies and media is very important to foster student responses or positive attitudes and lead to good learning outcomes. However, Angraini (2017) found that good learning media does not necessarily guarantee the success of student learning if we cannot use it well. For this reason, the media that we have chosen correctly must be utilized to the best of our ability by the principles of media use, that is, each media has advantages and disadvantages, and the use of media must be able to treat students actively.

It cannot be denied that the teacher's role has shifted from what was original as a source of information to the teacher as a facilitator in learning activities. The Teacher-Centered Learning model has switched to Student-Centered Learning. Rudatin (2015) found this shift where the teacher here is a facilitator, does not need to do much "chalk-and-talk" routine but can provide relevant conclusions in the learning process. This student-centred learning process requires student creativity, student awareness and the need to be carried out with full motivation so that the learning objectives can reach the students.

Although the learning process uses technological sophistication, the teacher's role is still very much needed, so teachers need to update themselves to the trends of modern learning and technology. Related to this, the teacher needs to put himself/herself as a motivator, which is to direct students for accessible learning resources. As a dynamist, which is to monitor students to develop their creativity and imagination. As an evaluator and justifier, which can assess and provide notes, additions, treasury and so on to the students' findings (Wartomo, 2016).

Regarding technology in learning, PhET as a virtual laboratory is an alternative that can be used as a medium for strengthening the concepts of physics given, in this case, the photoelectric effect. PhET can be chosen if the laboratory at school or the university does not have the tools needed. PhET can also show physical phenomena that cannot be seen by the naked eye through animation with an eye-catching display and many things that can be explored from this media. Tüysüz (2010) found that the use of virtual laboratories can overcome some of the problems faced with inadequate laboratory equipment and make a positive contribution in achieving learning goals. Although it is very helpful, the use of $\mathrm{PhET}$ in blended learning must remain with the supervision of the teacher as a facilitator with careful learning planning so that the student learning experience is more optimal.

Blended learning with the flavor of the flipped classroom can foster a positive attitude towards learning Modern Physics, especially for the topic of Photoelectric Effect. That positive attitude is also one of the factors in optimizing student learning outcomes. The positive side of Blended-Flipped 
Classroom Learning is linear with literature research by Slomanson (2014) which is found that Blended Learning with Flipped Classroom approach is a strategy that nearly everyone agrees on and also has a broad positive agreement. So that this learning model can be used as a refreshing alternative for learning in class, not only for Physics or Science topics but can also be tried for other topics or subjects.

\section{CONCLUSION}

Blended-Flipped Classroom Learning is a learning method that combines blended learning, which is a blend of traditional in-class learning components and e-learning components, with flipped classroom learning, which is a learning activity when students learn subject matter from the learning video at home before class begins and teaching and learning activities in class in the form of assignment and discussion of materials or problems that are not understood by students. This learning model requires the teacher who acts as a facilitator, dynamist, evaluator and also justifier.

From the result of the research conducted it can be concluded that student learning outcomes after Blended-Flipped Classroom Learning were in the "high" and "very high" category, where most students $(85.7 \%)$ were in the very high category. This result indicates that learning using Blended-Flipped Classroom Learning helps students to achieve optimal learning outcomes. Student responses to BlendedFlipped Classroom Learning were in the "good" category. It also shows that students' positive responses to the learning process can influence the optimization of their learning outcomes.

The findings show that Blended-Flipped Classroom Learning can be used as a reference for teachers so that the learning process is not only interesting and fun but can also provide optimal learning outcomes for students. A good and conducive learning environment is expected to be of more special attention by the teacher. This is because a good and conducive learning environment can affect students' positive interest in the learning process and this is reflected in good student learning outcomes.

\section{REFERENCES}

Agustya, Z., \& Soejoto, A. (2017). Pengaruh respon siswa tentang proses pembelajaran terhadap hasil belajar siswa kelas X pada mata pelajaran ekonomi di SMA Negeri 1 Wonoayu Kabupaten $\begin{array}{lllll}\text { Sidoarjo. Jurnal Pendidikan } & \text { Ekonomi (3). }\end{array}$ https://jurnalmahasiswa.unesa.ac.id/index.php/jupe/article/view/21461

Andresta, E. D., Sudarmi, M., \& Pattiserlihun, A. (2018). Increasing students ' communication skills using stimulant question model. Journal of Science \& Science Education, 2(2), 47-61. https://ejournal.uksw.edu/josse/article/view/1926

Angraini, R. (2017). Karakteristik media yang tepat dalam pembelajaran Pendidikan Kewarganegaraan (PKn) sebagai pendidikan nilai. Journal of Moral and Civic Education, 1(1), 14-24. https://doi.org/10.24036/8851412020171116

Arikunto, S. (2016). Dasar-dasar evaluasi pendidikan (5th ed.). Bumi Aksara.

Arnold-Garza, S. (2014). The flipped classroom teaching model and its use for information literacy instruction. Communications in Information Literacy, 8(1), 7-22. https://doi.org/10.15760/comminfolit.2014.8.1.161

Azis, P. A. (2016). Relationship of interest, learning motivation and attitude with results learning class VIII SMP State 13 Makassar. Journal of Educational Science and Technology (EST), 2(3), 144. https://doi.org/10.26858/est.v2i3.2700

Enfield, J. (2013). Looking at the impact of the flipped classroom model of instruction on undergraduate multimedia students at CSUN. TechTrends, 57(6), 14-27. https://doi.org/10.1007/s11528-0130698-1

Husamah, H. (2015). Blended project based learning: thinking skills of new students of biology education department (environmental sustainability perspective). Jurnal Pendidikan IPA Indonesia, 4(2), 110-119. https://doi.org/10.15294/jpii.v4i2.3878

Ilahi, N. W., \& Imaniyati, N. (2016). Peran guru sebagai manajer dalam meningkatkan efektivitas proses pembelajaran. Jurnal Pendidikan Manajemen Perkantoran, $1(1), \quad 99$. https://doi.org/10.17509/jpm.v1i1.3343

Johnson, G. B. (2013). Student perceptions of the flipped classroom [University of British Columbia]. 
https://doi.org/10.14288/1.0073641

Kadir, H. A. (2006). Preview panduan menjadi fasilitator efektif. PTS Professional Publishing Sdn.

Kim, K.-J., Bonk, C. J., \& Oh, E. (2008). The present and future state of blended learning in workplace learning settings in the United States. Performance Improvement, 47(8), 5-16. https://doi.org/10.1002/pfi.20018

Machin, A. (2012). Pengaruh permainan call cards terhadap hasil belajar dan aktivitas pembelajaran biologi. Jurnal Pendidikan IPA Indonesia, 1(2), 163-167. https://doi.org/10.15294/jpii.v1i2.2134

Mulyana, A., Hidayat, S., \& Sholih, S. (2013). Hubungan antara persepsi, minat, dan sikap siswa dengan hasil belajar siswa dalam pembelajaran PKn. Jurnal Pendidikan Dan Kebudayaan, 19(3), 315. https://doi.org/10.24832/jpnk.v19i3.291

Oktavianti, E., Handayanto, S. K., Wartono, W., \& Saniso, E. (2018). Students' scientific explanation in blended physics learning with e-scaffolding. Jurnal Pendidikan IPA Indonesia, 7(2), 181-186. https://doi.org/10.15294/jpii.v7i2.14232

Peniati, E., Parmin, P., \& Purwantoyo, E. (2013). Model analisis evaluasi diri untuk mengembangkan kemampuan mahasiswa calon guru ipa dalam merancang pengembangan laboratorium di sekolah. Jurnal Pendidikan IPA Indonesia, 2(2), 107-119. https://doi.org/10.15294/jpii.v2i2.2711

Pratiwi, A., Sahputra, R., \& Hadi, L. (2017). Pengaruh model flipped classroom terhadap selfconfidence dan hasil belajar siswa SMAN 8 Pontianak. Jurnal Pendidikan Dan Pembelajaran Untan, 6(11). http://jurnal.untan.ac.id/index.php/jpdpb/article/view/22723

Prihatiningtyas, S., Prastowo, T., \& Jatmiko, B. (2006). Imlementasi simulasi PHET dan KIT sederhana untuk mengajarkan keterampilan psikomotor siswa pada pokok bahasan alat optik. Jurnal Pendidikan IPA Indonesia, 3(1), 95-101. https://doi.org/10.15294/jpii.v2i1.2505

Rogers, C. R. (1983). Freedom to learn for the 80's. Charles E. Merrill Pub. Co.

Rudatin, R. M. D. (2015). Dari teacher centered learning menuju student centered learning (Studi kasus tentang proses pembelajaran di SMA N 1 Manyaran). SOSIALITAS: Jurnal Ilmiah Pend. Sos Ant, 5(2). https://jurnal.fkip.uns.ac.id/index.php/sosant/article/view/6406

Rukmini, E., Cindy, C., \& Tanoto, P. (2018). Student-centered learning in relation to class performances and soft skills: A meta-analysis and systematic review. Jurnal Pendidikan Kedokteran Indonesia: The Indonesian Journal of Medical Education, 7(2), 93. https://doi.org/10.22146/jpki.39098

Sanjaya, W. (2016). Strategi pembelajaran berorientasi standar proses pendidikan. Prenada Media. https://doi.org/2008

Schultz, D., Duffield, S., Rasmussen, S. C., \& Wageman, J. (2014). Effects of the flipped classroom model on student performance for advanced placement high school chemistry students. Journal of Chemical Education, 91(9), 1334-1339. https://doi.org/10.1021/ed400868x

Slomanson, W. R. (2014). Blended learning: A flipped classroom experiment. Journal of Legal Education, 64(1), 93-102. https://jle.aals.org/home/vol64/iss1/6/

Soimah, I. (2018). Pengaruh media pembelajaran berbasis komputer terhadap hasil belajar IPA ditinjau dari motivasi belajar siswa. Natural: Jurnal Ilmiah Pendidikan IPA, 5(1), 38. https://doi.org/10.30738/natural.v5i1.2559

Suyanto, E. (2009). Pengembangan contoh lembar kerja fisika siswa dengan latar penuntasan bekal awal ajar tugas studi pustaka dan keterampilan proses untuk SMA Negeri 3 Bandar Lampung. Prosiding Seminar Nasional Pendidikan-Universitas Lampung.

Tüysüz, C. (2010). The effect of the virtual laboratory on students' achievement and attitude in chemistry. International Online Journal of Educational Sciences, 2(1), 37-53. http://www.iojes.net//userfiles/Article/IOJES_167.pdf

Wartomo, W. (2016). Peran guru dalam pembelajaran era digital. Prosiding Temu Ilmiah Nasional Guru (Ting) VII, November, 265-275.

Zainuddin, Z., \& Keumala, C. M. (2018). Blended learning method within Indonesian higher education $\begin{array}{llll}\text { institutions. Jurnal Pendidikan 69-77. } & \text { Humiora, }\end{array}$ http://journal.um.ac.id/index.php/jph/article/view/10604 